\title{
The Effect of Perceived Deterrence on Compliance with Authorities: The Moderating Influence of Procedural Justice
}

\author{
Peter Verboon ${ }^{1, *}$ and Marius van Dijke ${ }^{2}$ \\ ${ }^{1}$ Open University of the Netherlands, The Netherlands \\ ${ }^{2}$ Rotterdam School of Management, Erasmus University, The Netherlands
}

\begin{abstract}
In order to stimulate compliance, authorities often use deterrence instruments. However, scientific literature from the fields of criminology, sociology and psychology has not been consistent in when or why deterrence is effective in shaping compliance.

In the present study we investigated the role of procedural justice in relation to deterrence. Procedural justice has strong effects on people's attitudes and behaviour regarding the social collective, including compliance with authorities. We argued that particularly authorities who are considered procedurally fair are successful in stimulating compliance with the use of deterrence instruments. In support of these ideas, a field survey in which we focused on sanction severity as the first element of deterrence and an experiment in which we focused on detection probability as the second element of deterrence revealed that procedural justice and deterrence instruments interactively strengthen each other's effect in promoting compliance. These finding may partly explain the sometimes-contradictory results from prior work about the effectiveness of deterrence by supporting a justice perspective on the effectiveness of deterrence in increasing compliance with authorities.
\end{abstract}

Keywords: Deterrence, sanction severity, detection probability, procedural justice, compliance.

For a stable and prosperous society, it is necessary that most people comply with the laws and regulations. A common way for authorities to stimulate compliance with their rules and decisions is by using deterrence (i.e. ensuring that there is a chance of getting caught upon rule transgression and punishing transgressors). In the criminology literature, deterrence theory (e.g. Becker 1968; Nagin 1998) is based on the notion that people will compare the probability of getting caught upon rule transgression and the severity of the sanction with the positive consequences of rule breaking behaviour (Paternoster 1987).

Deterrence theory thus assumes that people primarily act according to their self-interested motives to avoid punishment and to optimize their selfish outcomes. However, a vast number of studies in criminology (e.g. Nagin and Paternoster 1993; Williams and Hawkins 1986), sociology (Fehr and Rockenbach 2003), economics (Fischer, Wartick, and Mark 1992; Varma and Doob 1998), and psychology (Wit and Wilke 1990) indicate that deterrence variables often influence compliance to a limited extent at best.

In the present paper, we will argue that deterrence is important to promote citizens' compliance. However, we will also argue that the self-interest perspective on deterrence is insufficient to understand it's workings

*Address corresponding to this author at the Department of Psychology, Open University of the Netherlands, Coolsingel 65, 3012 AC, Rotterdam, The Netherlands; Tel: 31-10 2771480; E-mail: Peter.Verboon@ou.nl and that, in fact, a justice perspective is necessary to understand when and thus also why people respond to deterrence with compliance to societal authorities. This justice perspective stresses that it is necessary for authorities to be considered legitimate in order for deterrence instruments to be effective in stimulating compliance. We expect this because citizens use deterrence instruments as information that informs them about which behaviour is considered appropriate in a social system.

\section{THE SELF-INTEREST PERSPECTIVE: DETERRENCE THEORY}

The first systematic approach to understand criminal behaviour and non-compliance was offered by Becker (1968). Becker's approach assumes that criminal behaviour results from rational choices of individuals, based on economic considerations. The expected utility of the criminal behaviour is weighted against the risk of detection and the severity of the punishment. Potential offenders weigh the expected costs and rewards associated with criminal behaviour and then choose to perform criminal behaviour when the rewards outweigh the costs. Similarly, potential offenders choose to comply with the rules when the expected costs outweigh the rewards. Although the basic deterrence model has been extended with many variables to better explain criminal behaviour (e.g., Grasmick and Bursik, Jr 1990; Nagin 1998; Piquero and Tibbetts 1996), the key elements of deterrence theory remain sanction severity and detection probability. 
An important area in which compliance plays a central role that concerns most people is tax paying. Deterrence in the field of tax paying has been widely studied. In the traditional economic approach of tax compliance (Allingham and Sandmo 1972) it is assumed that people's decisions to comply with tax authorities are primarily motivated by economic selfinterest. From this point of view people are mainly concerned with financial self-interest and deterrence is necessary to prevent people from tax cheating. Some important review studies about the effects of deterrence on tax compliance include: Carrol (1987), Fischer, Wartick, and Mark (1992), Kirchler, Hoelzl, and Wahl (2008). These studies show that both the probability of detection and the severity of sanctions generally have a small effect on non-compliance, where detection probability is usually considered to be more effective than sanction severity. These results are consistent with results reported in the criminological literature on deterrence (e.g., Klepper and Nagin 1989; Nagin and Paternoster 1993; Williams and Hawkins 1986).

In a non-criminal context research on the effects of deterrence systems on compliance and cooperation has shown that deterrence can increase compliance with authorities' decisions (e.g., Wit and Wilke 1990; Yamagishi 1986) although the effectiveness of such systems is often rather limited (Tyler 1990). Mulder (2009) and Verboon and Van Dijke (2011) argue that specific perceptions of a sanction system play an important role in understanding why deterrence is more or less effective. For example, retributive sanctions (Darley and Pittman 2003) are likely to evoke moral disapproval of the sanctioned behaviour and lead to more compliance than compensatory sanctions, which are merely seen as economic transactions (Gneezy and Rustichini 2000).

From a self-interest perspective we would expect that rational people in most countries of the world would be non-compliant because levels of deterrence are generally low (Braithwaite 2003; Elffers 2000; Tyler 1990). Yet, most people are generally compliant with authorities, pay their taxes and refrain from criminal behaviour. This implies that self-interest cannot be the only motive to explain compliance. Moreover, contrary to predictions from the self-interest perspective, Frey (2003) reported that deterrence can even have a negative effect on compliance, which he explained by the "crowding out effect", by which deterrence decreases the intrinsic motivation to comply. A similar effect was found by Gneezy and Rustichini (2000). In their study a sanction (fine) was installed for not cooperating, but most people considered this fine as a business transaction that decreased their cooperation because they felt no moral obligation anymore to cooperate (see also Fehr and Rockenbach 2003; Mulder, Van Dijk, De Cremer, and Wilke 2006).

A related finding was reported by Tenbrunsel and Messick (1999) who showed that installing a sanction system can evoke a "business frame" (i.e., a frame of mind that considers sanctions and cooperation both as transactions). Such a business frame fits in the selfinterest perspective. Contrary to Gneezy and Rustichini (2000) they found that deterrence was more effective for people who used a business frame to support their decisions. One conclusion that emerges from these sometimes contradictory results is that the self-interest perspective is insufficient to explain when and why deterrence is effective to stimulate compliance and also when and why most people refrain from criminal behaviour and generally comply with rules and regulations.

\section{THE JUSTICE PERSPECTIVE: PROCEDURAL JUSTICE}

To meet the problems concerning the self-interest perspective, approaches other than purely economic ones have been proposed (e.g., Cullis and Lewis 1997). Sociological and psychological insights have led to a greater understanding of why people comply with authorities. In this line of research, concepts like trust in authorities (Mulder, Verboon, and De Cremer 2009; Murphy 2004; Van Dijke and Verboon 2010), moral norms (Fehr and Rockenbach 2003; Wenzel 2004a) and perceived justice (e.g., Tyler 1990; Verboon and Van Dijke 2011; Wenzel 2004b) are used to foster a more comprehensive understanding of compliance.

Procedural justice refers to the perceived justice of procedures used to make allocation decisions (Lind and Tyler 1988). People evaluate the fairness of procedures using a number of different criteria. For instance, procedures are perceived as just when one is allowed to voice one's opinion about authorities' decisions (Thibaut and Walker 1975) and when authorities take decisions accurately and without regard for self-interest (Colquit 2001; Leventhal 1980).

One important consequence of enacting procedural justice is that authorities are perceived as legitimate (Gau, Corsaro, Stewart, and Brunson 2012; Tyler 2006). Authorities are legitimate when the public views 
them as not only possessing the legal but also the moral authority to enforce the law (Tyler 2006). A number of different studies have underlined the beneficial effects of legitimacy for authorities in terms of compliance, for instance, authority legitimacy promotes voluntary tax paying (Kirchler, Hoelzl, and Wahl 2008) and cooperating with the police, for instance by providing crime related information (Murphy, Tyler, and Curtis 2009; Sunshine and Tyler 2003).

As noted, a host of studies have revealed that fair procedures stimulate people to cooperate with authorities or voluntarily comply with decisions made by the authority. Justice appears to be important to people because they expect just procedures to guarantee just outcomes in the long term, increasing their willingness to invest in the social collective (Shapiro and Brett 2005; Thibaut and Walker 1975). In addition, being treated fairly by the authority representing the social collective communicates that one is a valued and respected member of this collective. This stimulates internalization of the collective's norms and, consequently, voluntary compliance with the authority's decisions (e.g., Tyler, Degoey, and Smith 1996; Wenzel 2002).

Procedural justice research yields evidence that cooperation and compliance can be established by other means than deterrence alone (Tyler 1990; Tyler and Huo 2002), that is, by treating people with procedural justice and respect. As a result, people will view authorities as more legitimate and entitled to be obeyed (Tyler 2006). This justice perspective thus suggests that when people experience procedural justice, they accept social rules, and voluntarily cooperate and comply with the rules (Tyler and Blader 2000; Tyler and Huo 2002). Tyler (2006, p309) compares the justice perspective with the self-interest perspective of deterrence as follows: "...people will obey laws, without the threat of sanctions, when they experience the criminal justice system and its authorities as acting justly."

\section{COMBINING THE JUSTICE AND THE SELF- INTEREST PERSPECTIVES}

The present research combines the justice and deterrence based perspectives on compliance with authorities. Specifically, we argue that the legitimacy that results from enacting procedures in a fair way is important for the effectiveness of deterrence in promoting compliance with authorities. This is because deterrence has an important symbolic component to it
(Mulder 2009). In other words, when authorities sanction non-compliance in severe ways and / or they put much effort into ensuring that rule transgression is detected, this communicates that this authority finds the rule transgression inacceptable. When a legitimate authority strongly sanctions rule transgressions, this implies that the authority reflects the norms of the collective. Deterrence enacted by an authority that is not perceived as legitimate is at best effective because of self-interest motives only, such as described by Becker (1968).

We are not the first to study the effects of deterrence in combination with justice concepts. For instance, in the criminology literature it was found that sanctions that are perceived as just tend to stimulate compliance because authorities are viewed legitimate, while unjust sanctions reduce the authorities' legitimacy resulting in less compliance (Paternoster et al. 1997; Sherman 1993). Sunshine and Tyler (2003) found that legitimacy of the police is the key factor to predict compliance with the law and cooperation with the police. Furthermore they found that procedural justice is far more effective in shaping legitimacy of the police than using the deterrence instrument. In the psychological literature Van Prooijen, Gallucci, and Toeset (2008) found that a sanction system is only effective when it is perceived as fair. In addition Verboon and van Dijke (2011) showed that more severe sanctions only stimulated compliance when authorities acted fairly, mainly because people made positive moral evaluations about the fair authorities.

The present study aims to add to this literature by explicitly combining the justice perspective with the self-interest perspective of deterrence in the context of everyday life. First, we will generalize the results found in criminological settings to more common social settings that are meaningful to an average citizen. Specifically, in the two studies that we report, we focus on citizens' compliance with rule and regulations in the context of measures for the recent financial crisis (Study 1) and in the context of compliance with tax authorities (Study 2). Furthermore, we will not simply compare the self-interest and the justice perspectives as two competing ways to explain behaviour, but we study how they interact with each other. Following the line of reasoning of Van Prooijen et al. (2008) and Verboon and Van Dijke (2011) we argue that the deterrent effects of sanction severity and detection probability are stronger when the authority is considered legitimate. Since legitimacy of an authority is primarily a consequence of procedural justice 
perceptions (Tyler 2006) we expect that the positive effect of deterrence on compliance and cooperation is stronger when people experience higher levels of procedural justice.

\section{STUDY 1}

Study 1 was a field study focusing on a topic that has dominated the news worldwide over the past years: the financial crisis. This study was intended to test our hypothesis in a setting that is relevant for respondents. Perceived sanction severity was used as an indicator of deterrence. The aim was to test whether people were willing to cooperate with an authority depending on two evaluations of the authority: first, whether this authority was expected to punish severely those who do not comply with the rules, and second, whether it was considered to enact procedures in a fair way.

\section{Method}

\section{Participants and Procedure}

One hundred and twenty eight Dutch citizens agreed to participate. The sample consisted of 56 men (44\%) and 72 women (56\%): varying in age from 19 to 72 years old, $M_{\text {age }}=42.8$ years, $S D_{\text {age }}=11.70$. Seven students were asked as part of an assignment in a methodology course to take a random sample of twenty citizens and to distribute the questionnaire among them. The samples were combined into one dataset. Confidentiality of the responses was explicitly guaranteed to the respondents.

The questionnaire started with a short introduction about the financial crisis.

\section{Measures}

Procedural justice was measured with four items (Cronbach's $\alpha=.77$ ): "Do citizens have a say in decisions of the authorities?", "Are all citizens equally treated by the authorities?", "Do the authorities treat the problems concerning the financial crisis with care?" "Do the authorities have sufficient respect for citizens?" $(1=$ no, absolutely not, 7 = yes, most certainly). These items refer to the key issues of procedural fairness (Leventhal 1980) and were developed for this research.

Sanction severity was measured with "How severe is someone punished who does not comply with the rules? $(1$ = very lenient, 7 = very severe $)$.

Compliance was measured with four items, following the text: Suppose the authorities create a fund to help people who are suffering because of the crisis. The questions then read $(1=n o$, absolutely not, 7 = yes, most certainly): "Would you support initiatives of the authorities to help citizens with financial problems because of the crisis?", "If the authorities would ask you to donate to this fund voluntarily, would you do it?", "If the authorities would propose that every citizen should donate to this fund, would you protest against it?"(recoded), "If the authorities would oblige every citizen to donate to this fund, would you resist?"(recoded). The average score over the four items was taken as an index of compliance (Cronbach's $\alpha=.61$ ).

\section{Results}

Table 1 shows descriptive statistics of the variables and intercorrelations. We tested our hypotheses using hierarchical regression. First all variables were standardized. At step 1 of the analysis, we entered the main effects of procedural justice and sanction severity. At step 2, we entered the interaction term of procedural justice and sanction severity. The interaction term was based on standardized versions of the predictors (Aiken and West 1991).

The analysis (see Table 2) revealed a significant main effect of procedural fairness $(B=.34, S E=.085$, $p<.001)$. As was expected higher levels of procedural justice correspond with higher levels of compliance. No significant main effect for sanction severity was found. However, the interaction between sanction severity and procedural justice appeared significant $(B=.19, S E=$ $.088, p<.05$ ). Simple slopes analyses (Aiken and West

Table 1: Descriptive Statistics of Variables in Study 1

\begin{tabular}{|c|c|c|c|c|c|}
\hline & M & SD & Com & PF \\
\hline \hline Compliance & 3.13 & 1.19 & 1.00 & & \\
\hline Procedural Fairness & 3.91 & 1.12 & $0.34^{\star *}$ & 1.00 & 0.13 \\
\hline Sanction Severity & 3.55 & 1.38 & -0.08 & 1.00 \\
\hline
\end{tabular}

Note: Table presents means, standard deviations and correlations between the study variables. ${ }^{* *} p<.01 ;{ }^{*} p<.05$. 
1991) as illustrated in Figure 1, show that sanction severity is positively associated with compliance $(B=$ $.07, S E=.122, n s)$ when procedural justice perceptions are high (1 $S D$ above the mean). When justice perceptions are low (1 $S D$ below the mean), severe sanctions decrease the willingness to comply $(B=-.31$, $S E=.122, p<.05)$.

Table 2: Regression Results of Compliance on Procedural Fairness and Sanction Severity in Study 1

\begin{tabular}{|c|c|}
\hline Dependent variable & Compliance \\
\hline \hline Step $2 R^{2}, R_{\text {ad, }}^{2} R_{\text {change }}^{2}$ & $.16^{\star *}, .14, .03^{*}$ \\
\hline Sanction severity & -.12 \\
\hline Procedural fairness & $.34^{\star * *}$ \\
\hline Procedural fairness $\times$ Sanction severity & $.19^{*}$ \\
\hline
\end{tabular}

Notes: Table presents $\beta$ coefficients at step 2 (which includes all main effects and interactions). $: p<.05, ": p<.01{ }^{* * *}: p<.001$.

\section{STUDY 2}

The second study differed in two important ways from the first. First of all, whereas we focused on sanction severity as an index of deterrence in Study 1, in Study 2, we decided to focus on detection probability, as the second main variable that makes up deterrence.

Second, in contrast to the cross-sectional method of Study 1 , we employed an experimental procedure in
Study 2 in which we manipulated both detection probability and procedural justice. Both survey and experimental designs have been criticized, respectively for their difficulties in arriving at internally valid (i.e., causal) and externally valid (i.e., generalizable) conclusions (Dipboye 1990). By combining both research designs to answer one question, (i.e., whether deterrence and procedural justice interactively strengthen each other's effects on compliance), we aimed the strengths of each research design to make up for the weaknesses of the other design. In order to make sure that our participants could connect with the research setting, we focused on compliance with the tax authority in this study.

\section{Method}

\section{Participants and Design}

We randomly assigned our participants to one of the four conditions that resulted from orthogonally manipulating detection probability (high versus low) and procedural justice (just versus unjust). A total of 142 participants (31 men, 111 women, varying in age from 18 to 70 years old, $M_{\text {age }}=37.4$ years, $S D_{\text {age }}=9.0$ ) were recruited from part time (working) university students who were engaged in various courses.

\section{Procedure}

Upon arrival in the classroom, students were asked whether they were willing to participate in a paper-and-

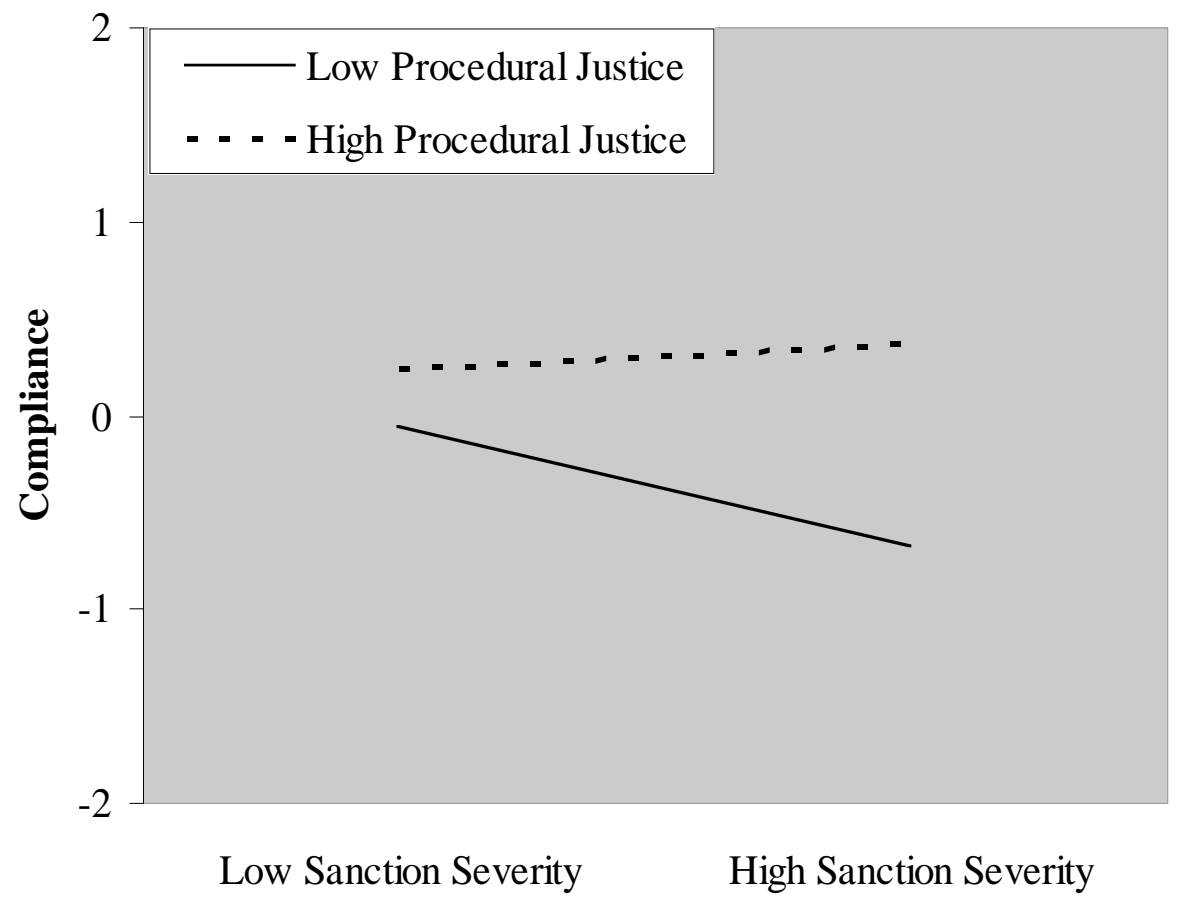

Figure 1: Compliance in Study 1 as a Function of Sanction Severity for High and Low Procedural Justice. 
Table 3: Compliance With Low and High Detection Probability Across Just and Unjust Procedures, Study 2 (N = 142)

\begin{tabular}{|c|c|c|c|c|c|c|}
\hline & \multicolumn{6}{|c|}{ Detection Probability } \\
\hline & \multicolumn{3}{|c|}{ Low } & \multicolumn{3}{|c|}{ High } \\
\hline & $N$ & $M$ & $S D$ & $N$ & $M$ & $S D$ \\
\hline Fair Procedures & 33 & 3.59 & 1.32 & 43 & 4.56 & 1.23 \\
\hline Unfair Procedures & 36 & 3.66 & 1.30 & 30 & 3.63 & 1.06 \\
\hline
\end{tabular}

pencil study. When students agreed they were given a scenario text and a questionnaire. Students then read a scenario and were asked to imagine that they had recently experienced the described situation. The scenario read as follows:

"You have received an announcement from the tax office to file your yearly income. Next to your regular salary, you received an amount of money this year for a one-time assignment for an acquaintance of yours. According to the law this money has to be declared to the tax office."

Then the procedural justice manipulation was introduced (derived from Leventhal 1980). Participants in the procedurally just condition read:

"When you call the tax office for more information you are given a clear and thorough answer. For instance, it is clearly explained to you under which circumstances you have to declare this money."

Participants in the procedurally unjust condition read:

"When you call the tax office for more information you are given an unclear and careless answer. For instance, it is not clearly explained to you under which circumstances you have to declare this money."

This was followed by the manipulation of detection probability. Participants in the high detection probability condition read:

"The detection probability of people who do not declare this money is rather high."

Participants in the low detection probability condition read:
"The detection probability of people who do not declare this money is rather low."

The dependent measures and manipulation checks of study 2 were then measured. All items were answered on 7-point scales (ranging from totally disagree [1] to totally agree [7]).

Finally participants were thanked and debriefed.

\section{Measures}

To check whether the procedural fairness manipulation was successful, participants were asked whether they considered the tax office "treated people with respect", "gave clear answers to questions", "gave careful answers", and finally "enacted fair procedures". These four items formed a reliable scale (Cronbach's $\alpha$ $=.70)$

To check whether the detection probability manipulation was successful, participants were asked whether they considered "the detection probability of someone who does not fully declare his income to be high".

Compliance to the tax rules was measured by asking whether participants would declare the extra income, using five items (Cronbach's $\alpha=.72$ ). The items are: "I will surely declare this extra income", "I will declare only a part of this extra income"(reversed), "I will pretend to have forgotten this extra income"(reversed), "I feel morally obliged to declare my income honestly" and "I don't feel like declaring this extra income" (reversed).

\section{Results}

\section{Manipulation Checks}

A $2 \times 2$ ANOVA on the procedural justice measure revealed a significant main effect of procedural justice, $F(1,140)=13.58, p<.001$. Participants in the just condition believed that the tax office acted more fairly than participants in the unjust condition ( $M s=4.50$ vs. 3.90; respectively). Neither a significant effect for the 
detection probability manipulation, nor a significant detection probability $\mathrm{x}$ procedural justice interaction was found.

A $2 \times 2$ ANOVA on the detection probability measure revealed a significant main effect of detection probability, $F(1,140)=17.53, p<.001$. Participants in the high detection probability condition believed that the detection probability was higher than in low detection probability condition ( $M s=4.41$ vs. 3.36 ; respectively). Neither a significant effect for the procedural justice manipulation, nor a significant detection probability $\mathrm{x}$ procedural justice interaction was found.

\section{Compliance}

A $2 \times 2$ ANOVA on compliance revealed, first of all, a significant main effect of procedural justice, $F(1,138)$ $=4.26, p<.05, \eta^{2}=.03$. Participants in the procedural just condition were more compliant than those in the unjust condition ( $M s=4.14$ vs. 3.65 ; respectively). Also a significant main effect of detection probability was found, $F(1,138)=4.93, p<.05, \eta^{2}=.03$. A high detection probability resulted in more compliance than a low detection probability $(M s=4.18$ vs. 3.63 ; respectively). As expected, these two main effects were qualified by a significant interaction between procedural justice and detection probability, $F(1,138)=$ 5.68, $p<.05, \eta^{2}=.04$ (see Figure 2). As predicted, the effect of detection probability on compliance was only present among those confronted with just procedures, $F(1,74)=10.80, p<.01, \eta^{2}=.13$, and not among those with procedural unjust procedures, $F(1,64)=$ $0.01, n s, \eta^{2}=.00$.

\section{DISCUSSION}

The aim of the present study was to show that deterrence as well as procedural justice are effective in stimulating compliance, and that these two factors do not function independently from each other. More specifically, our focus was whether perceived procedural justice of the authority moderated the effect of deterrence (i.e., sanction severity in Study 1 and detection probability in Study 2) on compliance. Taken together, the results of both studies clearly support our central prediction that procedural justice moderates the effect of deterrence on compliance with an authority.

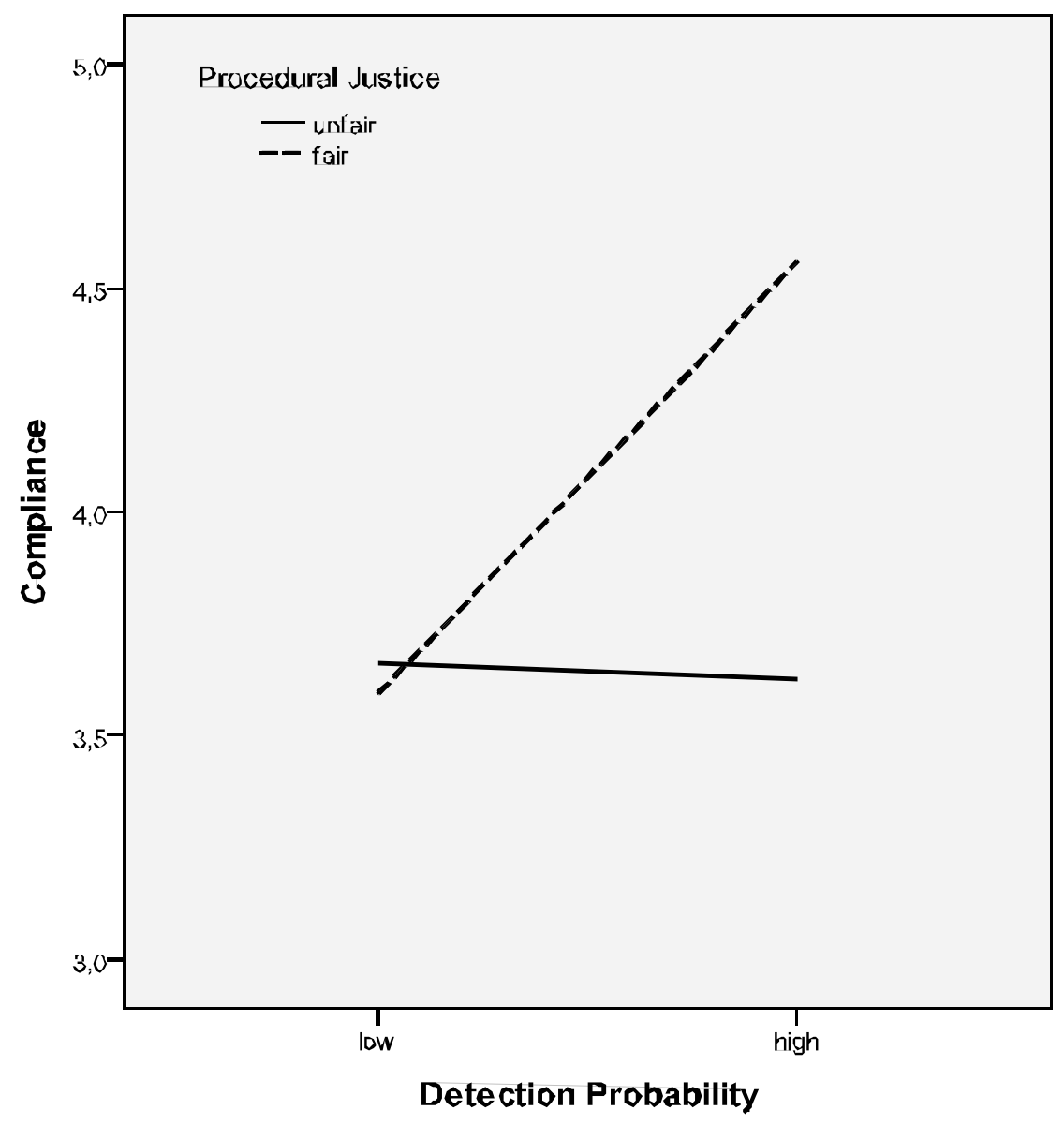

Figure 2: Compliance in Study 2 for Low and High Detection Probability across Unfair and Fair Procedures. 
Specifically, in the first study, a negative effect of sanction severity perceptions on compliance was found when procedural justice was low. In the second study no effect of detection probability was found when the procedures of the authority were considered unjust. And in both studies, we found positive effects of deterrence on people's compliance with the authorities' rules or request when procedural justice was high. These effects were small and not significant for sanction severity (Study 1) and significant for detection probability (Study 2).

The first study showed a negative relation between sanction severity and compliance among persons who considered the authorities as unjust. Although we expected sanction severity to be positively related to compliance, this outcome has been reported before, such as in studies that report that sanctions can undermine compliance (De Dreu, Giebels, and Van der Vliert 1998; Fehr and Rockenbach 2003; Gneezy and Rustichini 2000; Kirchler 2007; Mulder, Van Dijk, De Cremer, and Wilke 2006; Tenbrunsel and Messick 1999; Van Prooijen, et al. 2008). Moreover, the interaction effect we found in the first study is consistent with our arguments: without justice deterrence has a small and in this example even a negative effect on compliance. An explanation for the negative sanction effect may be that in this study sanction severity was measured as a property of the authority. There was no explicit relation suggested between the dependent variable (cooperation) and the sanction variable. That is, participants should infer that not cooperating might lead to severe sanctions. In this way the relation between deterrence as a self-interest motive and cooperation may be weakened and be more dependent on other aspects of the authority, such as procedural justice.

Our result confirms previous findings concerning sanction severity as reported for example by Van Prooijen et al. (2008), Varma and Doob (1998) and Verboon and Van Dijke (2011). As mentioned above the main effects of sanction severity on compliance have shown mixed results (Verboon and Van Dijke 2007; Wenzel 2004b). The present study may partly explain these mixed results since the effect of sanction severity depends on procedural justice perceptions. Studies in which no or small deterrence effects were found may be different from studies in which larger effects were found because differences in the perception of the authorities (with respect to procedural justice) were not accounted for in these prior studies.
The results imply that the effect of deterrence on compliance cannot be explained by instrumental motives (fear of punishment) alone. Procedural justice would not have moderated the relation between deterrence and compliance if deterrence would increase compliance only because of fear of the increased punishment. Therefore a justice perspective should be taken into account that emphasizes that the need for justice is important for people not only by directly influencing compliance behavior but also by indirectly influencing the effect of other variables on compliance. The results also suggest that deterrence is only partly based on rational choices and on selfinterest motives, and that it instead serves as an instrument to communicate the authorities' norms which may or may not be accepted (Depoorter and Vanneste 2005; Mulder et al. 2009).

The empirical fact that detection probability is a more powerful deterrent factor than the severity of the sanction (e.g., Kirchler, 2007) implies a costly consequence for a society, since expensive resources (e.g., audits, enforcement) to detect rule breaking need to be used. In reality detection probability appears to be fairly low for most criminal activities, and the public debate generally focuses more on harsh punishment than on more control. Fortunately, there may be a better solution, since it follows from this study, which confirms earlier work in the field of criminology (e.g. Sunshine and Tyler 2003; Tyler 2006) that authorities should focus their efforts more on increasing perceptions of procedural justice than on deterrence. The effects of procedural justice are generally stronger and more consistent than those of deterrence (e.g., Tyler 1990; Williams and Hawkins 1986), and deterrence effects depend on the justice perspective. Similar recommendations are made in the field of tax paying by Kirchler (2007) who emphasizes that the trust-based strategies are far more effective than power-based strategies. Even in situations where procedural justice does not seem to have a direct positive effect on compliance and detection probability seems necessary in stimulating compliance, as was shown in the second study, justice perceptions are an essential condition without which the deterrent effect of control disappears.

Although authorities can do their best to act in a just way, justice perceptions may be in the "eyes of the beholder" (Sherman 1993). In other words, whether an authority is perceived as just partly depends on characteristics of the citizens. For instance, people differ with respect to reciprocation ideology 
(Eisenberger, Cotterell, and Marvel 1987), a concept that explains why people have different views on what is meant by fairness. Understanding these differences in perception may become helpful in developing ideas about how authorities should act. Therefore, future research should also focus on individual differences with respect to justice and deterrence perceptions (Piquero, Gomez-Smith, Langton 2004).

Like all research, our studies also have several limitations that need to be discussed. The first study applied a cross-sectional design, with all variables derived from people's individual perceptions. Such a design limits causal conclusions and the main effects may be attributable to common method bias. The interaction effect, however, which was our primary interest, cannot be attributed to common method bias. On the contrary, as common method bias tends to inflate main effects, it tends to suppress interaction effects (Evans 1985; McClelland and Judd 1993). Hence, this study makes us rather confident in our observed interaction effect between procedural justice and deterrence on compliance with authorities.

Scenario studies that describe real life situations may be difficult to imagine for people who have had quite different experiences in these situations, thus threatening the validity of such a study. In our second study the scenario may have interfered with actual experiences people have had with the tax office. However, in the Dutch tax system many processes are automated and most people will not have interactions with tax office such as described in the scenario. Therefore, we do not expect that interference of this kind will cause large problems concerning the validity of the outcomes.

Another limitation is that both studies focused on "what-if" situations. No actual compliance was observed, but respondents reported what they would do in a given situation. For tax paying behavior it was found that self reported compliance does not always correlate strongly with actual tax paying (Hessing, Elffers, and Weigel 1988) although others report it does (Hite 1988; see also Verboon and Van Dijke (2011) for a discussion of this issue). Although research designs like ours are common practice in many scientific fields we advise that future research should also examine real compliance behaviour in relation to deterrence variables and procedural justice.

As a final limitation, we note that the two studies used different conceptualizations of deterrence (i.e., sanction severity and detection probability) and compliance (i.e., contribution to a common pool and declaring extra income). To further validate the conclusions from this paper future research should use validated measures that are similar across studies.

\section{CONCLUDING REMARKS}

This paper contributes to the understanding of the mechanism underlying the effects of deterrence on compliance with authorities. The results cannot be explained by taking only an instrumental perspective. In fact, a justice perspective appears helpful to understand how deterrence influences compliance. In sum, authorities should try hard to have people perceive their behaviour as procedurally just if they want their deterrence instruments to be more effective.

\section{REFERENCES}

Aiken, Leona S. and Stephen G. West. 1991. Multiple regression: Testing and interpreting interactions. New York: Sage.

Allingham, Michael G. and Agnar Sandmo. 1972. "Income tax evasion: a theoretical analysis." Journal of Public Economics 1: 323-338.

http://dx.doi.org/10.1016/0047-2727(72)90010-2

Becker, Gary S. 1968. "Crime and Punishment: An Economic Approach." Journal of Political Economy 76: 169-217. http://dx.doi.org/10.1086/259394

Braithwaite, Valerie. 2003. "Dancing with Tax Authorities: Motivational Postures and Non-Compliant Actions." Pp. 1539 in Taxing Democracy: Understanding Tax Avoidance and Tax Evasion, edited by V. Braithwaite. Ashgate: Hants, UK.

Carroll, John S. 1987. "Compliance with the Law: a Decision-Making Approach to Taxpaying." Law and Human Behavior 11: 319335. http://dx.doi.org/10.1007/BF01044744

Colquitt, Jason A. 2001. "On the Dimensionality of Organizational Justice: A Construct Validation of a Measure." Journal of Applied Psychology 86: 386-400. http://dx.doi.org/10.1037/0021-9010.86.3.386

Cullis, John G. and Alan Lewis. 1997. "Why people pay taxes: From a conventional economic model to a model of social convention." Journal of Economic Psychology 18: 305-321. http://dx.doi.org/10.1016/S0167-4870(97)00010-X

Darley, John M. and Thane S. Pittman. 2003. "The Psychology of Compensatory and Retributive Justice." Personality and Social Psychology Review 7: 324-336. http://dx.doi.org/10.1207/S15327957PSPR0704 05

De Dreu, Carsten K. W., Ellen Giebels, and Evert Van de Vliert. 1998. "Social Motives and Trust in Integrative Negotiation: The Disruptive Effects of Punitive Capability." Journal of Applied Psychology 83: 408-422. http://dx.doi.org/10.1037/0021-9010.83.3.408

Depoorter, Ben and Sven Vanneste. 2005. "Norms and Enforcement: The Case against Copyright Litigation." Oregon Law review 84: 1127-1179.

Dipboye, Robert L. 1990. "Laboratory vs. Field Research in Industrial and Organizational Psychology." International Review of Industrial and Organizational Psychology 5: 1-34.

Eisenberger, Robert, Norman Cotterell, and Joan Marvel. 1987. "Reciprocation ideology." Journal of Personality and Social Psychology 53: 743-750.

http://dx.doi.org/10.1037/0022-3514.53.4.743 
Elffers, Henk 2000. "But Taxpayers Do Cooperate!" Pp. 84-194 in Cooperation in Modern Society. Promoting the Welfare of Communities, States and Organizations, edited by M. van Vught, M. Snyder, T. R. Tyler, and A. Biel. London: Routledge.

Evans, Martin G. 1985. "A Monte Carlo Study of The Effects of Correlated Method Variance in Moderated Multiple Regression Analysis." Organizational Behaviour and Human Decision Processes 36: 305-323. http://dx.doi.org/10.1016/0749-5978(85)90002-0

Fehr, Ernst and Bettina Rockenbach. 2003. "Detrimental effects of sanctions on human altruism." Nature 422: 137-140. http://dx.doi.org/10.1038/nature01474

Fischer, Carol M., Martha L. Wartick, and Mike M. Mark. 1992. "Detection Probability and Taxpayer Compliance: A Review Of The Literature." Journal of Accounting Literature 11: 1-46.

Frey, Bruno, S. 2003. "The Role of Deterrence and Tax Morale in Taxation in the European Union." in Jelle Zijlstra Lecture 2002. Wassenaar: NIAS.

Gau, Jacinta M., Nicholas Corsaro, Eric A. Stewart, and Rod K. Brunson. 2012. "Examining macro-level impacts on procedural justice and police legitimacy." Journal of Criminal Justice 40: 333-343.

http://dx.doi.org/10.1016/j.jcrimjus.2012.05.002

Gneezy, Uri and Aldo Rustichini. 2000. "A Fine Is a Price'." Journal of Legal Studies 29: 1-17. http://dx.doi.org/10.1086/468061

Grasmick, Harold G. and Robert J. Jr Bursik. 1990. "Conscience, Signficant Other, and Rational Choice: Extending the Deterrence Model." Law and Society Review 24: 837-861. http://dx.doi.org/10.2307/3053861

Hessing, Dick J., Henk Elffers, and Russell H. Weigel. 1988. "Exploring the limits of self-reports and reasoned action: An investigation of the psychology of tax evasion behavior." Journal of Personality and Social Psychology 54: 405-413. http://dx.doi.org/10.1037/0022-3514.54.3.405

Hite, Peggy A. 1988. "An examination of the impact of subject selection on hypothetical and self-reported taxpayer noncompliance." Journal of Economic Psychology 9: 445466.

http://dx.doi.org/10.1016/0167-4870(88)90013-X

Kirchler, Erich. 2007. The Economic Psychology of Tax Behaviour. Cambridge University Press. http://dx.doi.org/10.1017/CBO9780511628238

Kirchler, Erich, Erik Hoelzl, and Ingrid Wahl. 2008. "Enforced versus voluntary tax compliance: The 'slippery slope' framework." Journal of Economic Psychology 29: 210-225. http://dx.doi.org/10.1016/i.joep.2007.05.004

Klepper, Steven and Daniel Nagin. 1989. "Tax Compliance and Perceptions of the Risks of Detention and Criminal Prosecution." Law and Society Review 23: 209-240. http://dx.doi.org/10.2307/3053715

Leventhal, Gerald, S. 1980. "What Should Be Done with Equity Theory? New Approaches to the Study of Fairness in Social Relationships." Pp. 27-55 in Social Exchange: Advances in Theory and Research edited by K. Gergen, M. Greenberg, and R. Willis. New York: Plenum.

Lind, Edgar A. and Tom R. Tyler. 1988. The Social Psychology of Procedural Justice. New York: Plenum Press.

McClelland, Gary H. and Charles M. Judd. 1993. "Statistical difficulties of detecting interactions and moderator effects." Psychological Bulletin 114: 376-390. http://dx.doi.org/10.1037/0033-2909.114.2.376

Mulder, Laetitia B. 2009. "The Two-fold Influence of Sanctions on Moral Norms." Pp. 169-180 in Psychological Perspectives on Ethical Behavior and Decision Making, edited by D. De Cremer. Charlotte, NC: Information Age Publishing.
Mulder, Laetitia B., Eric van Dijk, David De Cremer, and Henk A. M. Wilke. 2006. "Undermining trust and cooperation: The paradox of sanctioning systems in social dilemmas." Journal of Experimental Social Psychology 42: 147-162.

http://dx.doi.org/10.1016/j.jesp.2005.03.002

Mulder, Laetitia B., Peter Verboon, and David De Cremer. 2009. "Sanctions and moral judgments: The moderating effect of sanction severity and trust in authorities." European Journal of Social Psychology 39: 255-269. http://dx.doi.org/10.1002/ejsp.506

Murphy, Kristina. 2004. "The Role of Trust in Nurturing Compliance: a Study of Accused Tax Avoiders." Law and Human Behavior 28: 187-209. http://dx.doi.org/10.1023/B:LAHU.0000022322.94776.ca

Murphy, Kristina, Tom R. Tyler, and Amy Curtis. 2009 "Nurturing Regulatory Compliance: Is Procedural Justice Effective when People Question the Legitimacy of the Law?" Regulation and Governance 3: 1-26. http://dx.doi.org/10.1111/j.1748-5991.2009.01043.x

Nagin, Daniel, S. 1998. "Criminal Deterrence Research at the Outset of the Twenty-First Century." Pp. 1-42 in Crime and Justice vol. 23, edited by M. Tonry. Chicago: University of Chicago Press.

Nagin, Daniel S. and Raymond Paternoster. 1993. "Enduring Individual Differences and Rational Choice Theories of Crime." Law and Society Review 27: 467-496. http://dx.doi.org/10.2307/3054102

Paternoster, Raymond. 1987. "The deterrent effect of the perceived certainty and severity of punishment: a review of the evidence and issues." Justice Quarterly 4: 173-217. http://dx.doi.org/10.1080/07418828700089271

Paternoster, Raymond, Ronet Bachman, Robert Brame, and Lawrence W. Sherman. 1997. "Do Fair Procedures Matter The Effect of Procedural Justice on Spouse Assault." Law and Society Review 31: 163-204. http://dx.doi.org/10.2307/3054098

Piquero, Alex, R. and Stephen G. Tibbetts. 1996. "Specifying the Direct and Indirect Effects of Low Self-Control and Situational Factors in Offenders' Decision-Making: Toward a More Complete Model of Rational Offending." Justice Quarterly 13: 481-510. http://dx.doi.org/10.1080/07418829600093061

Piquero, Alex R., Zenta Gomez-Smith, and Lynn Langton. 2004 "Discerning unfairness where others may not: low self-control and unfair sanction perceptions." Criminology 42: 699-734. http://dx.doi.org/10.1111/j.1745-9125.2004.tb00534.x

Shapiro, Debra L. and Jeanne M. Brett. 2005. "What Is the Role of Control in Organizational Justice?" Pp. 155-178 in Handbook of Organizational Justice edited by J. Greenberg and J. A. Colquitt. Mahwah, NJ: Lawrence Erlbaum Associates Publishers.

Sherman, Lawrence W. 1993. "Defiance, Deterrence, and Irrelevance: A Theory of the Criminal Sanction." Journal of Research in Crime and Delinquency 30: 445-473. http://dx.doi.org/10.1177/0022427893030004006

Sunshine, Jason and Tom R. Tyler. 2003. "The Role of Procedural Justice and Legitimacy in Shaping Public Support for Policing." Law and Society Review 37: 513-548. http://dx.doi.org/10.1111/1540-5893.3703002

Tenbrunsel, Ann E. and David M. Messick. 1999. "Sanctioning systems, decision frames, and cooperation." Administrative Science Quarterly 44: 684-707. http://dx.doi.org/10.2307/2667052

Thibaut, John, W. and Laurens Walker. 1975. Procedural Justice: A psychological analysis. Hillsdale, NJ: Erlbaum.

Tyler, Tom R. 1990. Why People Obey the Law: Procedural Justice, Legitimacy, and Compliance. New Haven: Yale University Press. 
Tyler, Tom R. 2006. "Psychological perspectives on legitimacy and legitimation." Annual Review of Psychology 57: 375-400. http://dx.doi.org/10.1146/annurev.psych.57.102904.190038

Tyler, Tom R. and Steven L. Blader. 2000. Cooperation in Groups: Procedural Justice, Social Identity, and Behavioral Engagement. Philadelphia, PA: Psychology Press.

Tyler, Tom R., Peter Degoey, and Heather Smith. 1996. "Understanding Why the Justice of Group Procedures Matters: A Test of the Psychological Dynamics of the Group Value Model." Journal of Personality and Social Psychology 70: 913-930. http://dx.doi.org/10.1037/0022-3514.70.5.913

Tyler, Tom R. and Yuen J. Huo. 2002. Trust in The Law: Encouraging Public Cooperation with the Police and Courts. NY: Russell-Sage Foundation.

van Dijke, Marius and Peter Verboon. 2010. "Trust in authorities as a boundary condition to procedural fairness effects on tax compliance." Journal of Economic Psychology 31: 80-91. http://dx.doi.org/10.1016/j.joep.2009.10.005

van Prooijen, Jan-Willem, Marcello Gallucci, and Gaby Toeset. 2008. "Procedural justice in punishment systems: Inconsistent punishment procedures have detrimental effects on cooperation." British Journal of Social Psychology 47: 311324. http://dx.doi.org/10.1348/014466607X218212

Varma, Kimberly N. and Anthony N. Doob. 1998. "Deterring Economic Crimes: The Case of Tax Evasion." Canadian Journal of Criminology 40: 165-184.

Verboon, Peter and Marius van Dijke. 2007. "A self-interest analysis of justice and tax compliance: How distributive justice moderates the effect of outcome favorability." Journal of Economic Psychology 28: 704-727.

http://dx.doi.org/10.1016/i.joep.2007.09.004

Verboon, Peter and Marius van Dijke. 2011. "When do severe sanctions enhance compliance? The role of procedural fairness." Journal of Economic Psychology 32: 120-130. http://dx.doi.org/10.1016/j.joep.2010.09.007

Wenzel, Michael. 2002. "The Impact of Outcome Orientation and Justice Concerns on Tax Compliance: The Role of Taxpayers' Identity." Journal of Applied Psychology 87: 629645. http://dx.doi.org/10.1037/0021-9010.87.4.629

Wenzel, Michael. 2004a. "An Analysis of Norm Processes in Tax Compliance." Journal of Economic Psychology 25: 213-228. http://dx.doi.org/10.1016/S0167-4870(02)00168-X

Wenzel, Michael. 2004b. "The Social Side of Sanctions: Personal and Social Norms as Moderators of Deterrence." Law and Human Behavior 28: 547-567. http://dx.doi.org/10.1023/B:LAHU.0000046433.57588.71

Williams, Kirk R. and Richard Hawkins. 1986. " Perceptual Research on General Deterrence: A Critical Review." Law and Society Review 20: 545-572. http://dx.doi.org/10.2307/3053466

Wit, Arjaan and Henk A. M. Wilke. 1990. "The Presentation of Rewards and Punishments in a Simulated Social Dilemma." Social Behaviour 5: 231-245.

Yamagishi, Toshio. 1986. "The Provision of a Sanctioning System as a Public Good." Journal of Personality and Social Psychology 51: $110-116$. http://dx.doi.org/10.1037/0022-3514.51.1.110

DOI: http://dx.doi.org/10.6000/1929-4409.2012.01.15

(C) 2012 Verboon and Dijke; Licensee Lifescience Global.

This is an open access article licensed under the terms of the Creative Commons Attribution Non-Commercial License (http://creativecommons.org/licenses/by-nc/3.0/) which permits unrestricted, non-commercial use, distribution and reproduction in any medium, provided the work is properly cited. 